\title{
CONSTITUCIONALIZAR EL ORDEN FISCAL EN NUEVA ESPAÑA: DE LA ORDENANZA DE INTENDENTES A LA CONSTITUCIÓN DE CÁDIZ \\ $(1786-1814)$
}

\section{Ernest Sánchez Santiró}

Instituto de Investigaciones Dr. José María Luis Mora ${ }^{1}$

\section{INTRODUCCIÓN}

F $\mathrm{n}$ la segunda mitad del siglo xviII, los términos y expreEsiones constitución, constitucionalizar o dar constitución fueron muy frecuentes en los escritos jurídicos y de economía política en los distintos reinos que conformaron la Monarquía católica. ${ }^{2}$ De forma paralela, se produjo también una reflexión creciente en el campo del gobierno de la república que, a los usuales términos de vasallo, reino, estado y monarquía, asoció los vocablos de ciudadano y nación. ${ }^{3}$

Fecha de recepción: 7 de enero de 2015

Fecha de aceptación: 11 de febrero de 2015

${ }^{1}$ Este trabajo ha sido posible gracias al apoyo del Conacyt (proyecto núm. 153670).

2 Para la importancia de la economía política como espacio de reflexión asociado al problema del constitucionalismo ilustrado, consúltese PoRTILlo VALdÉs, "Entre la historia".

${ }^{3}$ Un buen ejemplo de ello lo tenemos en el Tratado de la regalía de 
Gracias a la mutua influencia de estas corrientes de pensamiento se fue generando lo que la historiografía ha denominado una "cultura del constitucionalismo" según la cual las bases firmes de la prosperidad de la nación, fincadas en la seguridad, la propiedad y la libertad de los vasallos/ciudadanos (todavía no eran palabras antitéticas), sólo podían lograrse mediante una Constitución, entendida ésta como un reordenamiento institucional que restringiera el poder del monarca en tanto que soberano. ${ }^{4}$ Se trataba, entre otros aspectos, de formalizar una restricción que limitara medularmente la capacidad de intervención de la corona sobre los bienes y el producto del trabajo de los vasallos, lo cual implicaba la reestructuración de uno de los principales instrumentos de gobierno de la monarquía: la Real Hacienda. Los diversos análisis y valoraciones sobre el estado de la monarquía y de su real erario, así como las propuestas de reforma de carácter constitucional que se habían ido elaborando durante la segunda mitad del siglo xviII, cobraron notable fuerza ante la crisis imperial de $1808-1810,{ }^{5}$ en la medida en que una de las soluciones institucionales ideadas

\footnotetext{
amortización de Pedro Rodríguez Campomanes (1765); en la introducción señala el propósito regalista de su obra: "Cuantos habitantes hay en el Reino son vasallos de V.M. y son Ciudadanos. La fuerza de la Nación es uno de los baluartes principales de la Iglesia, porque ella misma está dentro del Estado. V.M. pues por bien de la Religión debe admitir y proteger una Obra que demuestra lo que conviene a la Iglesia y al Estado. Tal es mi deseo, y éste ha sido el objeto de estudio". Rodríguez CampomaNEs, Tratado de regalía, s.p. [Aquí, y en el resto de textos, se ha actualizado la ortografía.]

${ }^{4}$ Portillo Valdés, "Entre la historia”; López Castellanos, “De las arcas reales", p. 2.

${ }^{5}$ Portillo Valdés, Crisis atlántica.
} 
radicó en la convocatoria de un proceso político constituyente que restaurara el gobierno de la Monarquía española, una entidad jurídica plural de alcance pluricontinental. Una presencia y vigencia que, sin embargo, experimentaron una notable adaptación y transformación según los contextos en los que se formularon y aplicaron. A la proclamación de un nuevo soberano, la nación española, le siguió la promulgación de una Constitución política de la Monarquía española que, en términos fiscales, reformuló de raíz la categoría jurídica de los contribuyentes y la naturaleza, el carácter y el papel a desempeñar por la entidad exactora, la naciente Hacienda pública. Con ello se generó una nueva articulación e interacción entre los dos componentes básicos de la ecuación fiscal, a saber: los egresos que originaban la defensa, la impartición de justicia y la administración hacendaria, como principales rubros del gasto, y los ingresos que emanaban de las contribuciones (impuestos, derechos y monopolios) que debían cubrirlos.

Siguiendo estas transformaciones, y en el espacio específico de Nueva España, el presente trabajo se aboca a dos aspectos. En un primer momento, se rastrean las iniciativas que hemos denominado constitucionalización del erario regio novohispano, en el marco de una tradición jurídica corporativa empapada de la analogía antropomórfica. Bajo este fenómeno se considera la reconfiguración institucional de la Real Hacienda acaecida entre 1781 y 1793, a raíz de uno de los momentos más intensos del reformismo ilustrado de los Borbones en Nueva España. En un segundo momento, se detiene en los retos planteados por la Constitución política de la Monarquía española de 1812 al naciente erario público en Nueva España, sometido éste a las presiones 
de una cruenta guerra civil que impidió en gran medida su desarrollo institucional.

Con esta exposición pretendemos mostrar la pluralidad que existió en la cultura político fiscal novohispana en torno a los sentidos y alcances que se podían adscribir a los procesos de constitucionalización, así como el impacto diferencial que manifestaban en materia de gobierno y administración del erario (regio y público/nacional, según las coyunturas) y sobre el régimen de contribuciones.

\section{LA CONSTITUCIONALIZACIÓN DE LA REAL HACIENDA \\ DE NUEVA ESPAÑA}

Entre el siglo xvi y la primera década del XviI, se establecieron los elementos institucionales básicos que dieron su fisonomía a la Real Hacienda de Nueva España, entendiendo por éstos la creación de impuestos, derechos y monopolios y la implantación de una incipiente administración hacendaria para su recaudación, distribución y control. Iniciativas que fueron institucionalizadas mediante una normativa expresa pero también por la consolidación de prácticas reiteradas que devinieron tradiciones fiscales.

Por medio de un proceso dilatado y casuístico, la corona introdujo un conjunto de rentas como soporte material para el gobierno y defensa de los vasallos del reino. Esta lógica financiera, unida a cuestiones políticas tan relevantes como el reconocimiento del vasallaje que debían los súbditos indígenas al monarca, el dominio eminente que detentaba la corona sobre ciertos recursos - era el caso de las minas-, el poder penal que ejercía el soberano por medio de sus jueces y tribunales, y la regalía fiscal que le habilitaba para establecer 
impuestos y crear monopolios, llevaron a la aparición de los tributos de indios y castas, los almojarifazgos de entrada y salida de los puertos, el quinto real de plata, los dos novenos reales, el estanco del azogue, el señoreaje de la moneda, la Bula de Santa Cruzada y las alcabalas. ${ }^{6}$ Esta estructura básica de ingresos creció en las décadas siguientes al establecerse nuevos impuestos y monopolios según la lógica de que la aparición de necesidades extraordinarias - generalmente bélicas, como resultado de la política internacional- exigía recursos adicionales. Si no se lograba establecer nuevos gravámenes o rentas anexas (las causas fueron variadas, no siendo menor la de la resistencia fiscal) quedaba el arbitrio de elevar las tasas de los impuestos existentes o aumentar los precios de los bienes sometidos a monopolio real - ya fuese de forma temporal o permanente-, así como la colecta de donativos graciosos, suplementos y préstamos.

Para la recaudación de los ramos fiscales, la distribución de los recursos y el control del erario regio, la corona creó una incipiente estructura de tesorerías territoriales, las cajas reales, ${ }^{7}$ y las contadurías, ${ }^{8}$ al frente de las cuales se colocó

${ }^{6}$ El tributo de indios tuvo su origen en 1521, mientras que el de castas de población libre descendiente de antiguos esclavos africanos se estableció en 1579; los almojarifazgos de entrada y de salida por los puertos del virreinato en 1522; el quinto real de plata en ese mismo año; los dos novenos que percibía la corona del diezmo eclesiástico en 1541; la renta del estanco del azogue que llegaba de España, en 1559; el señoreaje de la moneda que se acuñaba en la ceca mexicana en 1567; la Bula de Santa Cruzada en 1573 y, finalmente, la renta de las alcabalas en 1574. SÁnchez SANTIRó, Corte de caja, pp. 126-224.

7 Entre 1521 y 1599 se fundaron - por este orden - las cajas reales de México, Veracruz, Mérida, Guadalajara, Zacatecas, Acapulco y Durango. TePaske y Klein, Ingresos y egresos, t. I, pp. 14-15.

${ }^{8}$ La de tributos de México fue erigida en 1598. "Ordenanzas tocantes 
a "jueces oficiales reales" que actuaban de forma colegiada; en general se trataba de un contador, un tesorero $y$, menos frecuente, un factor. ${ }^{9}$ A su vez, se determinaron los mecanismos contables para el control de la gestión de las rentas mediante la denominada contabilidad de "partida simple" y de la obligación que tenían los oficiales de elaborar los libros manuales y comunes de cargo y data de las rentas de la Monarquía en cada uno de los distritos fiscales. Finalmente, en 1605 , se creó la cima institucional de la estructura hacendaria, el Real Tribunal y Audiencia de Cuentas de la ciudad de México, en tanto órgano de control superior de todas las cajas, contadurías, oficiales y libros de cuentas del reino de Nueva España y sus “provincias adyacentes” (Nueva Galicia, Nueva Vizcaya, Tabasco y Yucatán). ${ }^{10}$ Todos estos organismos quedaron, a su vez, sometidos en distintos grados y según las temporalidades a la supervisión última del virrey, al desempeñar el cargo de superintendente general de la Real Hacienda en Nueva España. ${ }^{11}$

a tributos y al contador dellos [sic] y del nuevo servicio y azogues", en “Ordenanzas para cinco tribunales desta [sic] ciudad de México”, Biblioteca Nacional (España), mss. 2940, f. 137.

9 Bertrand, Grandeza y miseria.

10 Este fue el término empleado por los ministros del Tribunal de Cuentas de México a mediados del siglo xviri. Sánchez Santiró, Corte de caja, p. 11.

11 La superintendencia general sólo fue una realidad plena hasta las reformas de 1746-1751, bajo el reinado de Fernando VI y durante el gobierno virreinal del primer Conde de Revillagigedo. Con anterioridad, diversos ramos (estanco del azogue, papel sellado, Bulas de Santa Cruzada, media annata, derechos de lanzas, etc.) disponían de jueces superintendentes con jurisdicción privativa que limitaba las facultades del virrey. SÁNCHEZ SAntiró, Corte de caja, pp. 302-304. 
En términos jurídicos, la Real Hacienda de Nueva España era parte constitutiva del Hispanus fiscus. ${ }^{12}$ Se trataba de un erario pluricontinental, con múltiples particularidades según los territorios, que presentaba una constante tensión entre sus aspectos "privados", en tanto que patrimonio del príncipe, y "públicos", al relacionarse con la soberanía y la res publica. Una tensión que, por ejemplo, podía ser mediada gracias a la figura de la "dote" (haciendo una analogía entre el matrimonio y la relación entre el rey y la república), según la cual los ingresos del fisco debían destinarse al mantenimiento de los gastos del monarca pero también a la conservación de la república; algo que remitía en gran medida a dos facetas básicas del soberano, como eran la defensa del reino (pro defensione regni) y la administración de la justicia. ${ }^{13}$ Todo ello acababa condicionando la entera disposición de los recursos al príncipe. ${ }^{14}$

Menesteres tan vitales para el mantenimiento del orden y la preservación de la Monarquía motivaron que la fuente de su soporte económico, el fisco regio, gozara de una posición

12 Clavero, "Hispanus fiscus".

13 Para estas responsabilidades básicas del monarca, véase SolóRZANo Y Pereira, Política indiana, p. 970.

${ }^{14}$ En tanto que patrimonio regio, el erario quedaba bajo el "dominio directo" y la "privada disposición" del monarca. Clavero, "Hispanus fiscus", pp. 131-138. No sólo se condicionaba la plena disposición de los recursos al monarca con motivo de la defensa del reino, también sucedía esto con algunos de los recursos transferidos a la Monarquía por la Iglesia, como ocurrió con el ramo de vacantes de obispos, los cuales, no sin conflicto, tuvieron que destinarse a partir de 1736 a costear "el viático, conducción, transporte y manutención de los misioneros apostólicos", o la obligación, no siempre respetada, de dedicar los ingresos de la Bula de Santa Cruzada a la defensa de la fe católica. Sánchez Santiró, Corte de caja, pp. 172-173 y 220-224. 
privilegiada que se materializó en la preeminencia de una hipoteca general en la ejecución de sus créditos frente a los de los vasallos. Un privilegio que, sin embargo, se vio continuamente sometido a interferencias y limitaciones por la concurrencia de otras entidades privilegiadas; era el caso de la Iglesia o de individuos que, por ejemplo, ostentaban privilegios por su estado de minusvalía (misera persona), entre varios supuestos. ${ }^{15}$

\section{Constitucionalizar la corporación: el caso de la minería novohispana}

Previamente a nuestra exposición sobre el erario regio, nos vamos a detener en la conformación del Tribunal de Minería de Nueva España y en la promulgación de sus ordenanzas con miras a señalar que nos encontramos ante un ejemplo de constitucionalización de una corporación de antiguo régimen. Un proceso que en la época se entendía como el otorgamiento, por parte del monarca, de un ordenamiento formal a un cuerpo, en este caso de oficio, lo que implicaba la creación de un órgano rector, en nuestro ejemplo, el Tribunal de Minería, y la promulgación de una normativa que le sirviera de herramienta de gobierno: las Ordenanzas de Minería. Como tal, estos cambios constituyen un claro precedente de lo que

15 Clavero, "Hispanus fiscus", pp. 124-127. Una muestra de esta situación se puede ver en la pugna entre las pretensiones de la Real Hacienda de Nueva España de asegurar el cobro del tributo de indios, concretamente bajo la figura de "medios tributarios", a las mujeres indígenas viudas y solteras, y las alegaciones de éstas ante la falta de "arbitrios" (recursos). Un enfrenamiento que se manifestó en un largo pleito durante la primera mitad del siglo XviII y que derivó, primero, en la suspensión temporal del pago en 1722 y, posteriormente, en la cancelación de la obligación fiscal en 1758. Sánchez Santiró, Corte de caja, p. 141. 
iba a experimentar la Real Hacienda de Nueva España durante el gobierno de José de Gálvez como ministro de Indias.

Una de las corporaciones presentes en la realidad social del virreinato de Nueva España fue el Cuerpo de Minería, también denominado simplemente "Minería", en el entendido de que con dicho nombre se designaba básicamente al conjunto de los mineros, en tanto agrupación de oficio, gremio pues, y no tanto a la actividad económica. ${ }^{16}$ Dicha corporación se fue implantado y desarrollando a medida que la actividad minera se propagó por el territorio del centro y norte de Nueva España, durante los siglos XVI y XviI. A esta expansión geográfica y crecimiento en la producción le correspondió una reglamentación primeriza que atendió a diversos ordenamientos castellanos y novohispanos, con un marcado carácter casuístico. ${ }^{17}$

Esta normativa minera novohispana surgió en el siglo XvI en el contexto de autorregulaciones en las modalidades de posesión y explotación de las minas y haciendas de beneficio de metales y en la obtención de mano de obra, como aspectos claves pero no únicos entre los propios mineros y de intervenciones de las autoridades reales, los alcaldes mayores y corregidores, en tanto jueces de minas, en los primeros reales mineros; básicamente nos referimos a los núcleos de Taxco, Sultepec, Zacatecas y Zumpango, a los que más

\footnotetext{
${ }_{16} \mathrm{Al}$ respecto es muy claro el sentido que da al término el rey Carlos III en el preámbulo a las Ordenanzas de 1783, haciendo sinónimos los términos "Minería" y "los Mineros de aquellos mis Dominios". Ventura BELEÑA, Recopilación sumaria, t. II, pp. 212-214.

17 Gerhard, Sintesis e indice, pp. 283-321; Enciso Contreras, Taxco en el siglo XVI; Enciso Contreras, Cedulario de Zacatecas; Enciso ConTRERAS, Zacatecas en el siglo XVI.
} 
tarde se añadirían Guanajuato y Pachuca. Esta regulación perseguía fundamentalmente dos propósitos. Por una parte, la ordenación de la actividad productiva y los aspectos contenciosos que se presentaran en la explotación de las minas. Por otra, se pugnaba por hacer respetar el régimen jurídico que establecía que las minas quedaban bajo el dominio eminente de la corona y del que se derivaba el pago de ciertos impuestos. ${ }^{18}$ Algo que debían vigilar los ministros de la Monarquía católica en el virreinato.

La situación de la minería novohispana comenzó a adquirir una nueva fisonomía a mediados del siglo xviıI. Tras una etapa de crecimiento de la producción, con mayores o menores tasas, desde finales del siglo XVII, la coyuntura de 1761-1767 se caracterizó por la interrupción de dicha tendencia. Frente a la expansión previa, la nota característica pasó a ser el estancamiento y la recesión. ${ }^{19}$ En ese escenario se elevaron distintas voces que desde el oficio público, el comercio y la propia minería, abogaron por la introducción de cambios que permitieran remontar la situación adversa. Unos defendían la reducción en la fiscalidad, otros la mejora en la provisión a bajos precios y la regularidad de los insumos (sal, azogue, pólvora, etc.), otros más abogaban por transformar los mecanismos de financiamiento o por cambiar las condiciones en las que operaba la mano de obra, especialmente reducir o eliminar el "partido" que percibían los operarios de ciertos reales. En este contexto propositivo, hubo quienes hicieron hincapié en el problema institucional.

${ }^{18}$ Ley IV, título XIII, del libro VI de la Recopilación de Castilla de 1567, también llamada la Nueva Recopilación. GonzÁlez, Ordenanzas de Minería, p. 84.

19 Hausberger, La Nueva España, pp. 71-72. 
Entre las diversas posturas que se plantearon en la época sobre este particular (que iban desde otorgar el control financiero pleno de la actividad minera a los mercaderes del Consulado de México hasta el fortalecimiento de la autonomía de los mineros) se optó por reestructurar y reforzar el espacio corporativo de la Minería en un complejo proceso de pesos y contrapesos que evitara la generación o el mantenimiento de monopolios por parte de alguna entidad en el orden corporativo novohispano. ${ }^{20}$

Como parte de esta política de ampliación y diversificación de organismos privilegiados se puede entender la creación del Tribunal de Minería en 1776. La historia concreta de su gestación (memoriales, proyectos, dictámenes de autoridades en diversas instancias, etc.) es bien conocida. ${ }^{21}$ Siguiendo el mismo preámbulo de las Ordenanzas de Minería de 1783, sabemos que en diciembre de 1771, el virrey Antonio María Bucareli y Ursúa hizo presente a Carlos III la necesidad de formar "nuevas Ordenanzas generales para dicho gremio, de modo que ellas uniformasen y abrazasen en todas sus partes el mejor método en su gobierno". En noviembre de 1773, el monarca indicó a Bucareli que junto a aquellas ordenanzas que habían de "formar a aquella Minería, la procurase arreglar y establecer en Cuerpo formal y unido a imitación de los Consulados de Comercio, para que de este modo lograsen sus individuos la permanencia, fomento y apoyo de que carecían”. En febrero de 1774, Lucas Lassaga y Joaquín Velázquez de León elevaron

20 SÁnchez SAntiró, "Privilegio versus monopolio".

21 Howe, The Mining Guild; Moreno, Joaquín Velázquez de León; González, Ordenanzas de Minería. 
una representación en la que los apoderados de los mineros de Nueva España no sólo demandaban la constitución del cuerpo de Minería, con sus respectivas ordenanzas, sino también la creación de un banco de avío y de un seminario/ colegio de metalurgia para elevar la cualificación técnica de los que dirigían las explotaciones.

A efectos del problema que tratamos aquí, sobresale el hecho de que el conjunto de propuestas planteadas a la corona (Lassaga y Velásquez las denominaron arbitrios) se entendían como parte de un proceso destinado a fortalecer el gremio minero. Y todo ello bajo los principios políticos de una analogía antropomórfica de origen clásico y reelaboración medieval: ${ }^{22}$ se reformaba la minería para mantenerla en una "constitución” que permitiera responder a la complejidad y problemas que afectaban al sector. En este sentido, Lassaga y Velásquez afirmaron:

Los vasallos de V.M. [...] van a informar [...] sobre ciertos arbitrios [...] no sólo para remediar radicalmente los antiguos males que padece la Minería, sino para conservarla siempre en una robusta constitución, y aun para promoverla con el tiempo hasta aquel grado de aumento, de que la hacen capaz la felicidad de estos Reinos, y la aplicación de sus Habitantes. ${ }^{23}$

¿Y cuál era el problema institucional a remediar? Para los representantes de la Minería no cabía dudas: la carencia de un organismo rector, de una cabeza que gobernara y diera constitución formal al cuerpo:

22 Lalinde Abadía, "La 'persona ficta”, pp. 17-18; Lorente SARIÑENA, “Esencia y valor”, p. 293.

23 Lassaga y Velásquez, Representación, pp. 1-2. Las cursivas son nuestras. 
El Gremio, o Comunidad de los Mineros de esta Nueva España, es un Cuerpo (si merece este nombre) no solamente acéfalo, sino que carece de toda organización; pero cualquiera especie de hombres, que son de una misma profesión, ejercicio o destino debidamente ordenado a la sociedad humana, necesita de una cabeza homogénea, que pueda dirigir los miembros con un conocimiento íntimo de su verdadera naturaleza, índole y constitución. Es este un dogma de política, hijo de la razón, y que lo ha comprobado la experiencia de todas edades y Naciones, en el estado civil y militar, eclesiástico, secular y religioso. ${ }^{24}$

Se trataba de crear una cima institucional, el Tribunal de Minería, y de elaborar un nuevo instrumento de gobierno, las Ordenanzas de Minería de Nueva España, para responder a los retos que enfrentaba el sector. El reordenamiento debía mantener los aspectos útiles de la normatividad heredada pero también posibilitar la adaptación a la evolución vivida por la actividad minera en el transcurso de casi dos siglos. Estas peticiones (si bien no en su completa integridad) estuvieron presentes en la Real Cédula de Carlos III de $1^{\circ}$ de julio de 1776, en la que se aprobó "que el importante Gremio de Minería de la Nueva España se pudiese erigir y se erigiese en cuerpo formal como los Consulados de Comercio de mis Dominios". ${ }^{25}$ Finalmente, en 1783, se expidieron las Ordenanzas de Minería, que vinieron a coronar las líneas maestras del cambio institucional propuesto. ${ }^{26}$ Volvamos ahora al real erario novohispano y apreciemos las similitudes del proceso de reforma.

24 Lassaga y Velásquez, Representación, pp. 24-25.

25 Ventura Beleña, Recopilación sumaria, t. II, pp. 213-214.

26 González, Ordenanzas de Minería. 
Reformismo borbónico y fiscalidad: uniformar y reconfigurar el gobierno de la Real Hacienda

Como aspecto inicial cabe señalar que los puntos generales expuestos brevemente hasta aquí, cuando señalamos el origen de las contribuciones y la estructura administrativa de la Real Hacienda de Nueva España, fueron alterados, sin ser negados, por las exigencias financieras emanadas de la política internacional de la nueva dinastía que gobernó la Monarquía católica tras la guerra de sucesión. En este contexto, el erario regio novohispano fue sometido a una demanda intensa de recursos durante tres coyunturas bélicas muy precisas del siglo xviII, que fueron previas al largo ciclo de conflictos originados tras la revolución francesa, a saber: la guerra de la oreja de Jenkins (1739-1748), la guerra de los siete años (1761-1763) y la guerra de independencia de Estados Unidos (1779-1783). ${ }^{27}$

A la par que los principales estados europeos pugnaban con desigual suerte por transformarse en estados fiscales militares (Fiscal-Military States), ${ }^{28}$ con sus crecientes demandas de ejércitos permanentes y estructuras hacendarias más eficientes, se desarrolló dentro de la Monarquía católica un debate sobre las reformas que debían aplicarse para responder a las necesidades emanadas de la política internacional de la corona. En el caso de Nueva España, los diversos pareceres se articularon en torno a la conveniencia

${ }^{27}$ La cronología se refiere a la participación española en dichos acontecimientos bélicos, no a la de las guerras en sí.

${ }^{28}$ Para el caso europeo en comparación con Oriente, consúltese TorRes Sánchez, War, State and Development. En el de los espacios iberoamericanos, véase Carrara y SÁnchez, Guerra y fiscalidad. 
de implantar o no el régimen de intendencias de ejército y de provincia.

Ambas posturas se polarizaron alrededor de figuras e instituciones relevantes, como sucedió con el virrey Marqués de Croix, el visitador general y posterior ministro de Indias, José de Gálvez, el fiscal de la Real Hacienda de la Audiencia de México, Ramón de Posada y Soto, o el virrey segundo Conde de Revillagigedo, quienes apoyaron la medida, no sin matices; o como sucedió con el oidor de la Audiencia de México, Francisco Leandro de Viana - futuro Conde de Tepa-, y los virreyes Antonio María Bucareli y Ursúa y Manuel Antonio Flores, como ejemplos notorios de la oposición a su establecimiento o como actores que encontraron en el sistema problemas de imposible solución, tras haberse adoptado la decisión. ${ }^{29}$

¿Dónde radicaba la disyuntiva? Para los principales promotores del régimen de intendencias, concretamente para el virrey Marqués de Croix y el visitador general, José de Gálvez, según su plan de intendencias de 1768 , se consideraba que el reino estaba "en decadencia y ruina" y para superarlo debía procederse como en España tras la guerra de sucesión, es decir, introducir las intendencias. Una solución que implicaba uniformar "su gobierno al de la Metrópoli". 30

Tras aceptar el monarca la propuesta y aprobar en 1769 la implantación de la intendencia en la provincia de Sonora, se vio la necesidad de obtener más información sobre el

${ }^{29}$ BRAding, Mineros y comerciantes; Pietschmann, Las reformas borbónicas.

30 "Informe dado al Excmo. Sr. D. Antonio María Bucareli sobre si conviene o no el establecimiento de Intendencias en Nueva España. Julio 1 de 1773", Biblioteca del INAH, fondo Antigno, exp. 55, fj. 8. 
procedimiento a desarrollar para llevar adelante la reforma global. En este contexto, el sucesor del Marqués de Croix, el virrey Antonio María Bucareli, más que aportar esta información pasó a impugnar el proyecto y para ello obtuvo un gran apoyo en el informe que sobre el particular emitió el oidor de la Audiencia de México, Francisco Leandro de Viana, fechado en julio de $1773 .{ }^{31}$ En su parecer, Viana señaló:

No es dudable la ruinosa Constitución de nuestra España antes del establecimiento de Intendencias, las dilatadas Guerras de la Sucesión aniquilaron a aquellos vasallos, las tropas enemigas desolaron a las Provincias, la Justicia se pervirtió, se abandonó por necesidad la Policía, y se introdujo la confusión y el desorden en la administración, cobranza y cuentas de la Real Hacienda. Nada de esto se verifica en la Nueva España, sino todo lo contrario; vivimos en una paz loable, no ha habido Guerras que destruyan las provincias, ni sus habitantes, la Justicia se distribuye con rectitud y la administración, cobranza y cuentas de Real Hacienda son las más exactas como se dirá en su lugar. ${ }^{32}$

Si bien pareciera que el problema a solucionar remitía a una cuestión de "constitución", entendida en este caso como un sistema de gobierno que cubriera cuatro facetas o "causas" (guerra, justicia, policía y hacienda), tal tesitura

31 Para esta polémica, Brading, Mineros y comerciantes, pp. 67-80. Cabe señalar que nuestro enfoque busca rescatar la cuestión de las intendencias novohispanas como un "problema de constitución".

32 Nótese la ordenación de las materias: guerra, justicia, policía y hacienda. "Informe dado al Excmo. Sr. D. Antonio María Bucareli sobre si conviene o no el establecimiento de Intendencias en Nueva España. Julio 1 de 1773”, Biblioteca del INAH, fondo Antiguo, exp. 55, fj. 10-10v. 
- afirmaba Viana - no era aplicable a Nueva España ya que su situación no era de decadencia o ruina, especialmente si se consideraba el floreciente estado del real erario; algo que Bucareli se encargó de mostrar de forma reiterada al monarca en sus numerosos informes sobre el particular. ${ }^{33}$

Las resistencias y el bloqueo al nuevo sistema se hicieron evidentes. Sin embargo, su principal promotor, José de Gálvez, no abandonó el proyecto al acceder a la Secretaría del Despacho de Indias (1776-1787). De hecho, fue durante su gestión cuando se procedió a ensayar lo que consideramos fue una reforma de carácter constitucional de la Real Hacienda de Nueva España desde un prisma corporativo, por la que cabe entender una reconfiguración del gobierno del erario regio que se desarrolló en cuatro facetas y momentos. Veámoslos.

Primeramente, se procedió a la creación de la fiscalía de Real Hacienda de la Real Audiencia de México en 1781. Por primera vez el erario regio novohispano contó con un fiscal especializado para la resolución de conflictos y cuestiones que le afectaban en materia judicial, cuando hasta entonces esta función la había desempeñado por lo regular el fiscal de lo civil de la Audiencia. ${ }^{34}$

En segundo lugar, se proyectó la homogeneización del sistema contable de las cajas reales y las contadurías de rentas. En 1784, Francisco Machado Fiesco, contador general del Consejo de Indias, expidió una "Instrucción práctica" para los erarios americanos en la que resaltan dos novedades. En primer lugar, la sustitución del sistema contable de

33 Bовв, The Vice-Regency.

${ }^{34}$ Rodríguez García, El fiscal de Real Hacienda. 
"partida simple" por el de "partida doble", en el que los conceptos de "debe y haber" reemplazarían a los de "cargo y data”, que era el que existía hasta entonces, ya que, según, Machado Fiesco...

[...] el Cargo y la Data se contrae más comúnmente al que lleva las cuentas, y así se pone en el Cargo lo que recibe, y en la Data pone lo que paga. Pero Intituladas las cuentas con los nombres de los Ramos, son éstos y no el Oficial Real, los que se apersonan, y es más consiguiente usar el nombre de Debe para cargarles lo que por ello se paga, y del Haber lo que se cobra por su cuenta. ${ }^{35}$

Una medida que debía redundar en un manejo más rápido y confiable de los caudales del monarca al permitir un cotejo expedito de la entrega de fondos y de su destino. La segunda novedad contable se enfocó a la delimitación precisa de la titularidad y destino de los diferentes ramos fiscales que componían o eran administrados por el erario regio. Para ello, el Tribunal de Cuentas de México estableció en 1785 tres categorías, a saber:

[...] los [ramos] de Real Hacienda afectos a cargas comunes; en la segunda: los de Real Hacienda afectos a cargas o destinos particulares; y en la tercera clase los Ramos ajenos de Real Hacien$d a$, que entran en Reales Cajas, con agregación de los que no tienen ingreso y subsiguen a los de primera clase con el título de Gastos de Real Hacienda, y otros que previene la Instrucción citada $[\ldots] .^{36}$

35 Donoso Anes, "Nuevo método", p. 824.

36 AGN, Archivo Histórico de Hacienda, vol. 1183. 
Con este sistema de clasificación contable de los ramos fiscales, el erario regio podía determinar de manera clara en cada una de las cajas reales los recursos que pertenecían al monarca y que debían emplearse de forma general en el reino de Nueva España y sus provincias adyacentes (ramos comunes), los que le pertenecían pero debían destinarse a un cometido específico en el propio reino o en la metrópoli (ramos particulares) ${ }^{37}$ y aquellos que sin pertenecerle los administraba como expresión de la protección que otorgaba la corona a ciertos grupos y empleados (ramos ajenos).

En tercer lugar, en 1786, se introdujo el régimen de intendencias. En el campo de la Real Hacienda este sistema implicó dos novedades en sus órganos de gobierno: la superintendencia subdelegada de la Real Hacienda y la Junta Superior homónima. Por lo que atañe al primer aspecto, esta modificación significó el tránsito de la superintendencia general de la Real Hacienda de Nueva España, detentada desde mediados del siglo XviII por el virrey, a la superintendencia general subdelegada que pasaría a ejercer el intendente de México, el cual quedaría bajo el control de la superintendencia general que pasaba a ostentar el secretario de Estado y del Despacho Universal de Indias. En este caso, es notable la pretensión de retirar el control del erario regio al virrey de Nueva España para entregarlo a un funcionario de menor rango, el intendente de la provincia de México, quien quedaría jerárquicamente sujeto a las directrices del ministro de Indias. ${ }^{38}$ Respecto a la Junta Superior de Real Hacienda, su creación

37 Por ejemplo, en esta situación se hallaba el estanco del tabaco en tanto que conformaba el principal recurso que debía nutrir la creciente necesidad de remesas para al erario metropolitano.

38 Pietschmann, Las reformas borbónicas, pp. 135-137. 
supuso el establecimiento de un órgano de gobierno colegiado del erario regio. A semejanza del Tribunal de Minería, se dotó a la Real Hacienda de una cabeza rectora con el fin de "uniformar su gobierno". ${ }^{39}$

Si bien en su composición y periodicidad era similar a las Juntas de Hacienda previstas desde el siglo xvII, ${ }^{40}$ había una novedad relevante que remitía a la función que debía cumplir la Junta Superior: "reducir en las provincias de aquel Imperio a un método igual, en cuanto fuere posible, el gobierno y administración de justicia en materias de mi Real Hacienda, y en lo económico de Guerra" ${ }^{41}$ Una uniformidad que, para llevarse a efecto, debía estar dirigida por un tribunal al que se le otorgaba jurisdicción privativa en materia de Hacienda, lo que implicaba la inhibición de otros tri-

39 Art. $4^{\circ}$ de la ordenanza de intendentes de Nueva España. Real Ordenanza, pp. 6-7. Pietschmann, Las reformas borbónicas, pp. 155-161, y Jáuregui, La Real Hacienda, pp. 85-90.

${ }^{40}$ En el caso de las Juntas de Hacienda se componían del virrey o presidente, el oidor de la Audiencia más antiguo, el fiscal de lo civil, el contador de Cuentas del Tribunal de Cuentas (donde lo hubiere) y del oficial real (contador o tesorero) más antiguo, mientras que en el caso de la Junta Superior de Real Hacienda por el intendente de México - a partir de octubre de 1787 su lugar fue ocupado por el virrey-, el regente de la Real Audiencia, el fiscal de Real Hacienda de la Audiencia de México, el contador mayor del Tribunal de Cuentas y el oficial real más antiguo de la Tesorería General de Ejército y Real Hacienda de México. Por lo que hace a la periodicidad, las reuniones se realizarían como mínimo una vez a la semana. Al respecto véanse Ley 8 , título $3^{\circ}$ del libro $8^{\circ}$ de las Leyes de Indias, así como el Art. $4^{\circ}$ ya citado: Recopilación de las Leyes [consulta: http://www.congreso.gob.pe/ntley/LeyIndiaP.htm], s.p. y Real Ordenanza, pp. 6-7. JÁuRegui, La Real Hacienda, pp. 85-90.

${ }^{41}$ Art. $6^{\circ}$ de la ordenanza de intendentes de Nueva España. Real ordenanza, pp. 9-10. 
bunales, quedando bajo la sola dependencia del monarca. Dicho tribunal era la Junta Superior de Real Hacienda. ${ }^{42}$

La cuarta y última faceta tuvo que ver con la creación de un instrumento de gobierno previsto en la ordenanza de intendentes de 1786: la elaboración, entre 1790 y 1793, por encargo del virrey segundo Conde de Revillagigedo, del Libro de la Razón General de la Real Hacienda de Nueva España. Nos hallamos ante una verdadera recopilación del ordenamiento jurídico del erario regio novohispano mediante el cual, y en palabras de los dos encargados de realizarlo, Fabián Fonseca y Carlos de Urrutia, "hallarán los jefes superiores de la monarquía y el reino, y los particulares de las direcciones y subalternos empleados en el despacho de las oficinas, resueltas y declaradas cuantas dudas suelen ocurrir a cada paso, y les embarazan el desempeño y pronta ejecución de sus ministerios". ${ }^{43}$

Vistas en conjunto, las medidas adoptadas estaban diseñadas para dotar al erario regio de Nueva España de una nueva forma de articular las relaciones fiscales entre los vasallos y la corona, así como el funcionamiento y los mecanismos de control que ejercía el monarca sobre sus oficiales y tribunales de Hacienda. Y todo ello en el contexto de un proyecto que pretendía "uniformar" y "poner en buen

${ }^{42}$ En el mismo Art. $6^{\circ}$ de la ordenanza se señala: "cuidando privativamente la expresada Junta Superior no sólo de los dichos dos ramos o causas [Hacienda y Guerra], sino también del de los Propios y Arbitrios, y Bienes de Comunidad de los Pueblos; para cuya dirección y conocimiento la [sic] concedo cuanta jurisdicción y facultades sean necesarias, con absoluta inhibición de todos mis Tribunales, y la sola dependencia de mi Real Persona por la vía reservada del Despacho Universal de Indias”. Real Ordenanza, pp. 9-10.

${ }^{43}$ Fonseca y Urrutia, Historia de Real Hacienda, t. I, pp. ix-x. 
orden, felicidad y defensa mis dilatados Dominios de las dos Américas". ${ }^{44}$ Se trataba de una transformación profunda del erario que, en el marco de un planteamiento organicista, proponía ajustar las cargas de los vasallos a la "constitución" del Estado.

Viva constatación de estos postulados antropomórficos fueron los primeros apartados del "Prospecto" o "Introducción” al Libro de la razón general ya citado, en el que Fabián Fonseca y Carlos de Urrutia afirmaron:

No hay Estado que pueda florecer [...] ni conservarse sin unos fondos que, sufriendo las cargas indispensables a su constitución, le sirvan de sostén. [...] De estos principios nacieron el de mirar semejante tesoro con los respetos de sagrado [...] y también el de sujetarse los súbditos gustosamente a llevar el peso de las contribuciones como miembros del cuerpo político, a fin de ayudar a la cabeza que es el príncipe $[\ldots]^{45}$

El destino de estas iniciativas es conocido: la fiscalía y la Junta Superior de Real Hacienda se consolidaron como instancias fundamentales del gobierno del erario regio; la contabilidad de partida doble no pudo implantarse tras los ensayos del bienio de 1786-1787,46 aunque sí lo hizo la clasificación de ramos fiscales que proponía; la superintendencia subdelegada separada del cargo virreinal apenas perduró unos meses, mientras que el Libro de la razón general no pudo completarse en su cabalidad ante la falta de noticias de la totalidad de las cajas reales del virreinato; de hecho apa-

\footnotetext{
44 Real Ordenanza, pp. 1-2.

45 Fonseca y Urrutia, Historia de Real Hacienda, t. I, pp. i-ii.

46 Avella Alaminos, "La experiencia de la partida doble".
} 
reció publicado casi 50 años después (1845-1853) bajo el título de Historia de general de Real Hacienda. Sin embargo, y pese a sus limitaciones, el erario regio experimentó un notable cambio institucional al dotarse de una nueva "constitución" bajo los principios del orden jurídico de antiguo régimen, en la que sus mayores emblemas fueron la creación de la fiscalía de Real Hacienda de la Audiencia de México, la Junta Superior de Real Hacienda y la elaboración, si bien incompleta, del Libro de la razón general del erario regio novohispano.

NACIÓN, CIUDADANÍA Y HACIENDA PÚBLICA:

LA RUPTURA CONSTITUCIONAL EN NUEVA ESPAÑA

(1810-1814)

Si bien el conjunto de corporaciones que integraban el imperio español se movilizaron bajo el paradigma de la defensa de la "constitución histórica" 47 de la Monarquía católica para hacer frente al embate que supusieron los hechos ocurridos en Bayona en 1808, no pudieron mantenerse en su integridad el imaginario y la praxis historicista. Para dar respuesta a las diversas crisis que se superpusieron tras las abdicaciones y el estallido de la guerra en la península ibérica, no sólo se convocaron, en un hecho inédito y problemático, unas

\footnotetext{
47 En el contexto de 1808, y ejemplificado en los términos planteados por la ciudad de Puebla, por este concepto cabía entender "nuestras leyes y costumbres". Rojas, "Las ciudades hispanas". Para el tránsito entre un accionar político que se movía en el ámbito de la preservación del orden establecido a otro que pugnó por su redefinición político institucional, con la elaboración de una constitución escrita como herramienta fundamental, véase LORENTE, "Esencia y valor”.
} 
Cortes generales y extraordinarias de ámbito pluricontinental (con diputados procedentes de Europa, América y Asia) sino que dicha instancia, representante de un nuevo sujeto político, ${ }^{48}$ procedió a la elaboración de una Constitución escrita que reestructuró "las relaciones entre gobernantes y gobernados". ${ }^{49}$

La Constitución política de la Monarquía española de 1812 no sólo proclamó un nuevo titular de la soberanía, que pasaba a ser la nación española, sino que también estableció una definición jurídica novedosa de los elementos básicos de dicha entidad política, los españoles, en tanto que individuos que la componían. ${ }^{50}$ Una nación que estaba dotada de potestades (hacer leyes, ejecutarlas y aplicarlas en las causas civiles y criminales) y unos individuos sujetos de derechos, en especial "la libertad civil, la propiedad y los demás derechos legítimos" ${ }^{51}$ Con estos elementos básicos, y circunscrito al

${ }^{48}$ Especialmente candentes fueron los aspectos relativos a la determinación de la soberanía y la modalidad de representación. Para el engarce de las diversas crisis, véase Portillo Valdés, Crisis atlántica, pp.15-28. ${ }^{49}$ Para este uso del término Constitución, consúltese Garriga, "Orden jurídico".

${ }^{50}$ No está de más reiterar las definiciones constitucionales: "Art. 1. La Nación española es la reunión de todos los españoles de ambos hemisferios"; "Art. 5. Son españoles. Primero: Todos los hombres libres nacidos y avecindados en los dominios de las Españas y los hijos de éstos. Segundo: Los extranjeros que hayan obtenido de las Cortes carta de naturaleza. Tercero: Los que sin ella lleven diez años de vecindad, ganada según la ley en cualquier pueblo de la Monarquía. Cuarto: Los libertos desde que adquieran la libertad en las Españas". Para el término "individuos" véase el Art. 13: "El objeto del Gobierno es la felicidad de la Nación, puesto que el fin de toda sociedad política no es otro que el bienestar de los individuos que la componen". Tena Ramírez, Leyes fundamentales, pp. 60-62. ${ }^{51}$ Para una discusión historiográfica sobre los contenidos jurídicos de los términos nación, individuo y ciudadano, presentes en la Constitución de 
campo de la fiscalidad, este conjunto de mutaciones cristalizaron institucionalmente en el tránsito que va de la Real Hacienda a la Hacienda pública. ${ }^{52}$

Del repertorio de transformaciones que implicó el proceso, deseamos resaltar dos aspectos que emanaron directamente de la Constitución de Cádiz de 1812: por una parte, los efectos restrictivos, abolicionistas y prefigurativos que en materia de contribuciones planteó y, por la otra, las consecuencias derivadas de la eclosión del "vecino ciudadano", ${ }^{53}$ en tanto que sujeto de derechos y obligaciones fiscales. Unos elementos que nos permitirán ponderar el grado de aplicación que tuvieron estos preceptos en el orden fiscal novohispano, así como las tensiones que generaron.

Restricciones, aboliciones y prefiguraciones en materia de contribuciones

Como es conocido, la carta constitucional gaditana surgió en un contexto bélico plagado de penurias financieras que llevó a la aprobación de numerosos "arbitrios" extraordinarios llamados a cubrir los gastos de guerra y los heredados de la administración previa, así como los de los nuevos órganos políticos que fueron apareciendo, en especial la Junta Central, la Regencia y las Cortes generales y extraordinarias. ${ }^{54}$ Contribuciones temporales, rentas extraordinarias o préstamos forzosos, además de numerosos donativos

Cádiz, véase Clavero, “Cádiz, 1812”, en especial las 223-232; consúltese también Pietschmann, "Nación e individuo".

52 Chust y Serrano, "El Liberalismo doceañista”, pp. 58-59.

53 Portillo Valdés, “Entre la historia”, p. 27.

${ }^{54}$ Fontana y Garrabou, Guerra y Hacienda. 
y transferencias desde los territorios americanos, ${ }^{55}$ fueron algunos de los expedientes utilizados por las autoridades para cubrir, sin alcanzarlo plenamente, el déficit que se originaba del descuadre entre los impuestos, monopolios y derechos que se recaudaban en una península sometida a un estado de guerra y los crecidos gastos que había que financiar. ${ }^{56}$

Las enormes demandas financieras emanadas del conflicto bélico suponían un escenario de riesgo para el disfrute de la libertad, la propiedad y las rentas de los vasallos, elementos que, recordamos, habían sido invocados reiteradamente por los reformistas ilustrados hispanos al socaire de las reflexiones que emprendieron en materia de economía política cuando trataron sobre las relaciones entre la corona, $y$ más específicamente, el real erario y los vasallos. ${ }^{57}$

El nuevo orden político que se estaba creando enfrentó el conflicto restringiendo la capacidad de intervención de determinados actores políticos en materia de contribuciones. Bajo este principio se hizo evidente uno de los aspectos más garantistas de la Constitución de Cádiz cuando determinó que la única autoridad capacitada para aprobar o derogar las contribuciones y contratar préstamos serían las Cortes generales (Art. 131, secciones Decimatercia y Decimacuarta). ${ }^{58}$ No sólo esto. Para evitar posibles

${ }^{55}$ En el caso del apoyo financiero que desempeñaron los erarios americanos, en especial, el novohispano, consúltese MARICHAL, Bankruptcy of Empire; Valle Pavón, "Financiamiento".

${ }^{56}$ Para el conjunto de medidas que configuraron esta fiscalidad extraordinaria en España, véase López Castellanos, Liberalismo económico; LASARTE Álvarez, La contribución extraordinaria.

57 Portillo Valdés, “Entre la historia”; López Castellanos, “De las arcas reales".

58 Tena Ramírez, Leyes fundamentales, p. 75 
ambigüedades o huecos, este principio se reafirmó por la vía restrictiva al tratar de la persona del rey cuando, en la sección octava del Art. 172, se asentó: "no puede el Rey imponer por sí directa ni indirectamente contribuciones, ni hacer pedidos bajo cualquier nombre $[\ldots]$ sino que siempre los han de decretar las Cortes". ${ }^{59}$

La carta gaditana estipuló también un mandato abolicionista en materia de contribuciones, si bien de manera implícita, aunque su aplicación quedaba sujeta a una legislación posterior. En el Art. 354, se señaló: “No habrá aduanas sino en los puertos de mar y en las fronteras, bien que esta disposición no tendrá efecto hasta que las Cortes lo determinen". El impacto sobre uno de los principales rubros fiscales heredados del real erario español, las rentas provinciales (básicamente, las rentas de alcabalas, cientos y millones), en aquellos lugares en que no estaban encabezadas - que era la mayoría de las grandes poblaciones de España-, era demoledor: su cobro se hacía inviable sin el sistema de aduanas interiores que controlaba la entrada y salida de las mercancías con propósitos fiscales. ${ }^{60}$

Junto a estas facetas restrictivas y abolicionistas también existía en la Constitución una vertiente prefigurativa de las contribuciones, aunque en un inicio pudiera parecer lo contrario. En este sentido, y según el Art. 338, la carta gaditana semejó no decantarse por ninguna modalidad específica de tributación cuando declaró: "Las Cortes establecerán o confirmarán anualmente las contribuciones, sean directas

59 Tena Ramírez, Leyes fundamentales, p. 82. López Castellanos, Liberalismo económico, p. 257.

60 Angulo Teja, La Hacienda española. 
o indirectas, ${ }^{61}$ generales, provinciales o municipales, subsistiendo las antiguas, hasta que se publique su derogación o la imposición de otras". ${ }^{62}$

Ante la longeva disputa doctrinal y de grupos de interés que se había desplegado en el seno de la Monarquía católica desde mediados del siglo XVII y, sobre todo, durante el XviII, en torno a la necesidad de abolir las rentas provinciales (compuestas mayoritariamente por contribuciones indirectas) e introducir una contribución directa que las sustituyese (fue el caso de los debates sobre el "medio general" durante el reinado de Felipe IV - antes incluso de englobarse las diversas contribuciones indirectas bajo el rubro de rentas provinciales-, o el de la "única contribución”, en los de Fernando VI y Carlos III), ${ }^{63}$ parecía afirmarse una

61 La distinción terminológica entre contribuciones directas e indirectas no fue muy usual antes del siglo XviII. De hecho, sería con la escuela fisiocrática, en especial a partir de la doctrina sobre la fiscalidad de François Quesnay, publicada en 1758, que adquirió carta de naturaleza. Al respecto, véase Bullock, "Direct and Indirect". Entendemos por impuestos directos aquellos que gravan una manifestación duradera de la capacidad de pago de los contribuyentes, ya sea a partir de las fuentes de los rendimientos económicos (contribuciones de producto), ya a partir de la renta que perciben las personas (contribuciones personales), mientras que consideramos impuestos indirectos los gravámenes que recaen sobre manifestaciones transitorias de la capacidad de pago que se perciben con ocasión de actos contractuales, como por ejemplo los actos de compra venta y trueque de bienes muebles e inmuebles o el tránsito de mercancías. Comín, Historia de la Hacienda, pp. 46-48, y SÁnchez Santiró, Las alcabalas mexicanas, p. 20.

62 Tena Ramírez, Leyes fundamentales, p. 99.

63 Valladares, Banqueros y vasallos; Delgado Barrado, Aquiles y Teseos, Camarero Bullón, El debate de la Única Contribución; López Castellanos, Liberalismo económico, pp. 27-39. 
especie de falta de preferencia entre ambas modalidades de contribuciones ("sean directas o indirectas").

Aunque una parte de la historiografía ha considerado que las contribuciones directas surgían como corolario de los principios político fiscales proclamados en el artículo 339 de la Constitución, que, a la letra, estableció: "Las contribuciones se repartirán entre todos los españoles con proporción a sus facultades, sin excepción ni privilegio alguno", es posible apreciar que tal conexión no era del todo evidente. ${ }^{64} \mathrm{Si}$ bien esta formulación afirmó los principios de universalidad ("todos"), proporcionalidad ("con proporción a sus facultades") e igualdad ("sin excepción ni privilegio alguno") de los causantes ("los españoles") ante las contribuciones, no cabe interpretar por eso la necesaria generalización de las contribuciones directas. Una prueba de ello la tenemos en el estudio "histórico-doctrinal" y de "economía política” que tuvo que realizar la Comisión extraordinaria de Hacienda creada por las Cortes para establecer un plan general de contribuciones cuando entró al estudio de las rentas provinciales que, recordamos, estaban compuestas básicamente por las rentas de alcabalas, cientos y millones.

En su dictamen de 6 de julio de 1813, la Comisión extraordinaria mostró que al menos desde el siglo Xvir se había defendido que los impuestos que gravaban el consumo en la corona de Castilla cumplían con los principios invocados. Acudiendo al religioso franciscano Francisco Martínez Mata [Memorial o discursos en razón del remedio de la

${ }^{64}$ López Castellanos, Liberalismo económico, pp. 153-155; Serrano Ortega, "Liberalismo y contribuciones", pp. 187-189; Serrano OrteGA, Igualdad, uniformidad, proporcionalidad, pp. 12-14. 
despoblación, pobreza y esterilidad de España -1650-], la Comisión recordó que se había llegado a afirmar "que el modo de contribuir sobre los géneros de primera necesidad era el más proporcionado y justo que se podía hallar, porque cada uno paga según sus posibles". ${ }^{65}$

Para impugnar este pensamiento, los miembros de la Comisión extraordinaria de Cortes se vieron obligados a "demostrar" la falta de proporción que había entre la riqueza de los causantes y el acto económico del consumo, algo que se agravaba cuando se atendía a los productos de primera necesidad, ya que los diversos compradores no acudían al mercado en igualdad de condiciones; luego, la equiparación entre las contribuciones directas y la proporcionalidad de las contribuciones no era algo obvio. Hubo que dar un rodeo económico para poder afirmar que las rentas provinciales no cumplían con el criterio de proporcionalidad. ${ }^{66}$

${ }^{65}$ Informe de la Comisión, pp. 14-15. En esta defensa de las rentas provinciales, si bien con reformas, la Comisión podía acudir en lo inmediato a la memoria que elaboró Vicente Alcalá Galiano, tesorero general del ejército, en 1810 para mostrar su oposición al decreto de la Junta Central de 7 de agosto de 1809 que estableció la abolición de dichas contribuciones. Una medida que tendría efecto cuando se estableciesen las rentas que debían sustituirlas. López Castellanos, Liberalismo económico, pp. 168-192. ${ }^{66}$ En este punto, la Comisión extraordinaria de Hacienda continuó la senda trazada por gran parte de la literatura de economía política y del conjunto de propuestas de reforma fiscal que pugnaron en el siglo XviII por la sustitución de las rentas provinciales en la corona de Castilla. Para estos precedentes doctrinales, consúltese López Castellanos, Liberalismo económico. A pesar de todo, la crítica no alcanzó el grado de evidencia, lo que posibilitó que hasta bien entrado el siglo xIx se mantuviera, por ejemplo, el postulado de la proporcionalidad inherente a una contribución indirecta como lo eran las alcabalas, al defenderse que el consumo era un reflejo de la renta o ingreso de los causantes. Para el caso mexicano, véase SÁnchez SANTiró, Las alcabalas mexicanas. 
Retomando la carta constitucional, podemos apreciar que la "equidistancia" era mera apariencia. Tras afirmar, como hemos apuntado, la posibilidad de diversas modalidades de contribuciones (Art. 338), poco después, y sin mediación que diese mayores pistas, se establecía:

Art. 344. Fijada la cuota de la contribución directa, las Cortes aprobarán el repartimiento de ella entre las provincias, a cada una de las cuales se asignará el cupo correspondiente a su riqueza, para lo que el secretario del despacho de Hacienda presentará también los presupuestos necesarios. ${ }^{67}$

Dando por hecho el establecimiento de un gravamen general, lo que se refuerza por su enunciado en singular, llamado a gravar los capitales o el ingreso/la renta de los sectores económicos o de los individuos, ${ }^{68}$ el artículo en cuestión se limitaba a señalar el procedimiento de distribución de la carga fiscal entre las provincias de la Monarquía española. Es decir, no había ninguna equidistancia entre las diversas contribuciones. La Constitución de Cádiz optó claramente por la contribución directa. Consideramos que si el Art. 338 habló de las contribuciones indirectas cabe atribuirlo únicamente al hecho, planteado en el Art. 131 (en el

67 Tena Ramírez, Leyes fundamentales, p. 100. Las cursivas son nuestras. ${ }^{68}$ Esta disyuntiva tampoco era real, ya que desde el decreto de Cortes del 1ํㅡㄹ de abril de 1811, que reformó la contribución extraordinaria de guerra creada por la Junta Central en 1810, se había llegado a un consenso legislativo en el sentido de que la modalidad de contribuciones directas aceptables en términos de justicia y economía era aquella que gravara la renta de los españoles, no sus capitales, con el añadido de que el gravamen debía "graduarse por medio de una progresión equitativa”. SÁNCHEZ SAntiró, "La irrupción del liberalismo fiscal”, p. 15. 
título III, que trataba sobre las Cortes), de la facultad que tenía el legislativo de "Establecer aduanas y aranceles de derechos". Es decir, contribuciones indirectas que gravaran el comercio externo de la Monarquía española, ya fuera en sus aduanas marítimas o en las terrestres. Un elemento pues de regulación económica (y fiscal, claro está) de las relaciones internacionales de la Monarquía española con el resto de naciones. ${ }^{69}$

El "vecino ciudadano" constitucional y su impacto sobre las contribuciones y la administración hacendaria

De forma paralela a la estructura política, la territorialidad constitucional de la Hacienda pública de la Monarquía española se planteó en tres ámbitos: el municipal, el provincial y el nacional. En este entramado se interconectaron dos procesos de dirección inversa. Por una parte, la determinación de la carga fiscal que tenían que enfrentar los españoles y, por la otra, la recaudación de las contribuciones. Procesos que, como veremos, estuvieron unidos de forma inextricable a la introducción de la contribución directa.

En el primer caso, y como tarea previa que daba arranque a todo el proceso fiscal, las Cortes tenían que "fijar los gastos de la administración pública”, mientras que para cubrirlos debía "establecer anualmente las contribuciones y los impuestos" (Art. 31, apartados $12^{\circ}$ y $\left.13^{\circ}\right) .{ }^{70}$ Vemos aparecer aquí el principio de legalidad fiscal ${ }^{71}$ que, como luego

${ }^{69}$ Sección $17^{\mathrm{a}}$ del Art. 131. Tena Ramírez, Leyes fundamentales, p. 75.

70 Tena Ramírez, Leyes fundamentales, p. 75.

71 Lasarte Álvarez, Las Cortes de Cádiz, p. 372. 
trataremos, fue invocado por los causantes novohispanos. Sin embargo, lo que deseamos resaltar ahora es cómo, una vez determinado el monto de los egresos públicos, las Cortes debían establecer las contribuciones que los cubriesen, y para ello hemos visto que se pensó en la contribución directa y en las aduanas externas marítimas y terrestres, en este último caso de forma subsidiaria.

Ahora bien, para lograr certidumbre en el pago de las obligaciones fiscales se conectó la contribución directa con un sistema de cuotas y repartimientos entre territorios y causantes, tal como se realizaba en los distintos regímenes de contribuciones directas que se habían implantado en los territorios de la antigua corona de Aragón tras la guerra de sucesión, fuera el caso del catastro en Cataluña, el equivalente en Valencia, la única contribución en Aragón o la talla en Mallorca. ${ }^{72}$ Y aquí es donde entraba la primera dirección aludida, en este caso la que iba desde las Cortes, pasando por las diputaciones provinciales hasta llegar a los ayuntamientos constitucionales. Conocido por el legislativo el monto que debería sufragar la nación para mantener los gastos públicos, se cargaría una parte sobre la contribución directa y para ello se establecería una cuota sobre el conjunto de la riqueza nacional (cuyo valor sería preciso determinar). Dicho monto sería repartido por las Cortes entre las provincias mediante un sistema de cupos (Art. 344). La entidad encargada de repartir entre los ayuntamientos constitucionales de la provincia el cupo determinado a cada uno de ellos sería la diputación provincial (Art. 335). ${ }^{73}$ Finalmente,

72 Pro Ruiz, Estado, geometría y propiedad.

73 “Art. 335. Tocará a estas diputaciones: Primero: Intervenir y aprobar 
los consistorios, verdaderos núcleos políticos del orden constitucional, ${ }^{74}$ serían quienes repartirían entre todos los [vecinos] contribuyentes el cupo asignado por la diputación al ayuntamiento (Art. 321) ${ }^{75}$ De forma inversa, en la direccionalidad, las contribuciones serían recaudadas por los ayuntamientos, quienes trasladarían los fondos a las tesorería provinciales, las cuales pondrían estos fondos a disposición de la Tesorería General de la Nación. ${ }^{76}$

La novedad e impacto del sistema no puede minusvalorarse. El modelo hacendario gaditano presente en la Constitución conectó sin solución de continuidad los niveles territoriales de la estructura política con la Hacienda pública al ser las Cortes las que determinarían de forma previa el gasto y las contribuciones a recaudar, al establecer su reparto territorial y entre los contribuyentes según los niveles de dicha estructura (Cortes, diputaciones, ayuntamientos), y al convertir a los ayuntamientos y diputaciones en las oficinas de recaudación, movilización y control contable de las contribuciones, lo cual, y como derivación implícita,

el repartimiento hecho a los pueblos de las contribuciones que hubieren cabido a la provincia [...].” Tena Ramírez, Leyes fundamentales, p. 98. ${ }_{74}$ Puntos nucleares, al ser los ámbitos inmediatos de la práctica política de los vecinos ciudadanos, lo cual no sólo implicaba ciertas calidades, estados y clases de individuos - sexo, libertad, descendencia de naturales de ambos hemisferios, cumplimiento de las obligaciones fiscales, etc.-, sino también la vecindad, es decir, el arraigo y ejercicio de un oficio o condición en una localidad de la Monarquía, y de la cual se derivaban derechos y obligaciones. Clavero, "Cádiz, 1812".

75 “Art. 321. Estará a cargo de los ayuntamientos: [...] Cuarto: Hacer el repartimiento y recaudación de las contribuciones, y remitirlas a la tesorería respectiva." TENA RAMíREz, Leyes fundamentales, p. 96.

${ }^{76}$ Artículos 321, 345 y 346 de la Constitución de 1812. Tena Ramírez, Leyes fundamentales, pp. 96 y 100. 
volvía innecesarias las diversas oficinas y administraciones de rentas (concretamente, las de las rentas provinciales y las estancadas) heredadas de la Real Hacienda. Todos estos principios constitucionales fueron los que se pusieron en práctica, aunque por breve tiempo y con poco éxito, con el plan de contribuciones públicas aprobadas por las Cortes generales y extraordinarias el 13 de septiembre de $1813 .^{77}$

\section{La Hacienda pública constitucional en Nueva España}

Muy poco de todo lo que acabamos de mostrar se pudo poner en práctica en Nueva España, en especial en el primer momento de vigencia de la Constitución de Cádiz (18121814). El estado de guerra civil que se vivía desde 1810, en conjunción con la crisis política y el conflicto armado que había en España, llevó a que el orden fiscal del virreinato se gobernase bajo el principio de necesidad ("la imperiosa ley de la necesidad”), lo que provocó la acentuación paralela de otro principio ("lo que a todos atañe, todos deben aprobarlo”) según el cual la autoridad necesitaba del consentimiento de los vasallos para llevar adelante medidas fiscales que iban a detraer una porción de los bienes que poseían a título privado o de las rentas que generaban sus propiedades o

77 "Nuevo plan de contribuciones públicas", decreto CCCIV de 13 de septiembre de 1813, Colección de decretos y órdenes, pp. 229-241 [incluye la Instrucción a las diputaciones provinciales]. Para el conjunto de discusiones parlamentarias que dieron pie a este decreto, al igual que sobre los antecedentes doctrinales y administrativos del mismo, véase Informe de la Comisión; López Castellanos, Liberalismo económico; MartíNEZ DE MontaOs, El pensamiento hacendístico liberal. 
actividades económicas. ${ }^{78}$ Se trataba de dos regula iuris, ${ }^{79}$ en el marco del derecho común, que convenientemente invocadas por las autoridades exactoras o por los causantes fiscales delimitaron un espacio de negociación que permitió dar cauce a las tensiones hacendarias que aparecían de forma continua dado el escenario de guerra civil existente. El resultado más palpable en términos de contribuciones fue la intensificación de la fiscalidad extraordinaria, mientras que por parte de los causantes se justificó la suspensión o el aplazamiento del pago de impuestos como mecanismo de resistencia fiscal.

Este contexto de excepcionalidad provocado por la contienda bélica fue la base que permitió a las autoridades novohispana locales, regionales y virreinales modificar el cuadro tributario al alterar en un volumen y amplitud nunca vistos con anterioridad los antiguos impuestos y crear nuevos gravámenes. Una actividad reformadora que, como ejercicio de competencias, sólo se concebía como atribución del monarca, en tanto titular de la soberanía y, tras la promulgación de la Constitución, de las Cortes de la nación. Por otra parte, la conexión entre fiscalidad y representación, como espacio de negociación entre la corona y el orden corporativo, se realizó en un principio mediante diversas juntas de autoridades y de $\operatorname{arbitrios}^{80}$ en las que desfilaron desde el virrey, las

78 López de Goicoechea, “La Imago Regis”.

79 Para la pervivencia de este conjunto de máximas en el derecho mexicano de la primera mitad del siglo XIX, consúltese Rodríguez DE SAN Miguel, Pandectas Hispano-megicanas, t. III, pp. 685-704.

80 Para estas juntas con finalidad hacendaria, véanse JÁuregui, La Real Hacienda; SÁnchez SANTIRó, "Guerra y restauración” y "La irrupción del liberalismo". 
Audiencias (México y Guadalajara) y el Tribunal de Cuentas, hasta los subdelegados, cabildos y diputaciones locales de comercio y minería, entre otros organismos. El incumplimiento de esta máxima podía derivar en un conflicto entre la corona y los vasallos que acabara inhabilitando la actividad recaudatoria al elevar a niveles prohibitivos los costos de transacción, especialmente los de información y de ejecución obligatoria. ${ }^{81}$

Bajo estos parámetros se pudo establecer en el ámbito virreinal el derecho de convoy y el derecho sobre el vino mezcal en 1811, y la contribución de $10 \%$ sobre los arrendamientos de casas y la contribución temporal extraordinaria de guerra en $1812 .{ }^{82}$ Sin embargo, ante la aprobación de la Constitución de Cádiz en marzo de 1812 y su juramento por las autoridades virreinales cambió la lógica de funcionamiento. El mejor ejemplo de ello fueron los obstáculos que experimentó la contribución directa general y extraordinaria promovida por el virrey Félix María Calleja en 1813; una más de las iniciativas de gravámenes extraordinarios promovidas con motivo de la guerra civil que, sin embargo, tuvo que lidiar con el nuevo orden constitucional. Frente a la invocación de la ley de la imperiosa necesidad, los ayuntamientos constitucionales y las diputaciones provinciales, organismos emanados del nuevo orden político, adujeron la ilegalidad de la propuesta al contravenir lo previsto en el artículo 131 de la Constitución que, como vimos, señalaba que la única entidad capacitada para

\footnotetext{
${ }^{81}$ Para estos conceptos del enfoque neoinstitucional véase NORTH, Institutions, Institutional Change.

82 SÁnchez Santiró, "Guerra y restauración”.
} 
establecer las contribuciones eran las Cortes y no el monarca. Si esto era así, menos aceptable aún era que el virrey, una autoridad nombrada por el rey, procediera a tomar estas iniciativas. Algo que, como señalamos, la Constitución había restringido de forma expresa en su artículo 172 ("no puede el Rey imponer por sí directa ni indirectamente contribuciones, ni hacer pedidos bajo cualquier nombre [...] sino que siempre los han de decretar las Cortes"). ${ }^{83}$

Estos principios fueron continuamente invocados, junto con cuestiones de carácter técnico - como la falta de estadística- y de resistencia fiscal, por los ayuntamientos constitucionales y las diputaciones provinciales ${ }^{84}$ para oponerse a la implantación de un gravamen que en su formulación había asumido muchos de los principios promovidos por las Cortes en sus diversos decretos sobre contribuciones y presentes en la propia Constitución; de hecho se trataba de una contribución directa personal que gravaba la renta neta de los causantes (definidos en el bando que le dio vida como "todos los habitantes de este Reino") bajo una escala de progresividad. ${ }^{85}$ Sin embargo, la medida incumplía un

83 Tena Ramírez, Leyes fundamentales, p. 82.

${ }^{84}$ Serrano Ortega, "Liberalismo y contribuciones directas", pp. 190192; Serrano Ortega, Igualdad, uniformidad, proporcionalidad, pp. 33-38; SÁnchez Santiró, "La irrupción del liberalismo".

${ }^{85}$ AGN, Archivo Histórico de Hacienda, vol. 487, exp. 3. Es notable que se omitiera en la definición del causante la categoría de "españoles", combinación de origen étnico y vecindad, y que se primara únicamente la de residencia. También es destacable que en el reglamento de dicha contribución directa general y extraordinaria se hicieran convivir como causantes tanto las personas físicas ("los habitantes") como las personas fictas (las corporaciones civiles y eclesiásticas), algo inimaginable en el ordenamiento constitucional, donde los causantes sólo eran personas físicas: "los españoles". "Nuevo plan de contribuciones pública”, 
requisito básico que remitía a la legitimidad constitucional: la nación española por medio de sus representantes en las Cortes no había conocido ni aprobado la creación del nuevo gravamen. Algo que fue recordado por la Diputación provincial de Nueva Galicia en 1814, cuando se opuso a su introducción:

De la Constitución el expresado Excmo. Señor Virrey ya sea por esta alta dignidad ya por la de Jefe Político de la Nueva España, y ya también por la de superintendente general de la Hacienda pública no se halla según el juicio de la Diputación con facilidades algunas para establecer contribuciones y arbitrios ni hacer pedido alguno con cualquiera nombre o para cualquiera objeto. ${ }^{86}$

Un parecer que fue reiterado de forma contundente por el ayuntamiento constitucional de Veracruz en su representación a la Regencia, fechada el 19 de marzo de 1814, en el primer aniversario de la Constitución de Cádiz. En dicho documento, y tras analizar la lastimosa situación del virreinato desde 1810, se hacía una encendida defensa del régimen fiscal propuesto por las Cortes generales y extraordinarias, pero también una crítica acre y sin paliativos del proceder fiscal de los virreyes Venegas y Calleja al asumir éstos funciones que correspondían únicamente al poder legislativo. La piedra de toque para el consistorio veracruzano, una

decreto CCCIV de 13 de septiembre de 1813, Colección, 1813, pp. 229241. Para las diversas modalidades de personas jurídicas, consúltese Clavero, "Hispanus fiscus".

86 Diego-Fernández y Gutiérrez, “José de la Cruz”, p. 259. Nótese la paráfrasis del artículo 172 de la Constitución de 1812. 
vez más, era la cuestión de la contribución directa de Cortes frente a la que se había aprobado en Nueva España en diciembre de 1813:

La contribución directa establecida sobre las bases de equidad y justicia, arreglada a los principios de la ciencia económica, metodizada para su fácil ejecución, y que obre con la igualdad debida sobre todas las clases del estado, sin perjuicio notable de los individuos que la componen, es la más útil y conveniente entre los impuestos que se conocen; empero una contribución directa, arbitraria e impracticable, fundada en la ignorancia de los elementos económicos, dictada sin conocimientos de las circunstancias de las respectivas provincias, sin la consulta de la diputación provincial (que no se quiere instalar) sin oír el dictamen de los ayuntamientos, que deja subsistentes las gabelas, [...] una contribución al fin decretada traspasando las facultades del virreinato, y sin arreglarse a los principios constitucionales, es una infracción terminante de la octava restricción del rey; es un abuso de la libertad civil; un desenfreno del poder, una ofensa a las augustas resoluciones del cuerpo soberano $[\ldots] .{ }^{87}$

Si dicho gravamen pudo subsistir, aunque de forma breve - hasta 1815 - , con resultados muy escasos en términos de recaudación y después de transmutar su naturaleza política y denominación (pasó a llamarse subvención temporal de guerra), sólo cabe atribuirlo a la restauración absolutista ocurrida en el virreinato en septiembre de $1814 .^{88}$

${ }^{87}$ Bustamante, Cuadro histórico, pp. 18-19. Sobre este episodio véase Serrano Ortega, Igualdad, uniformidad, proporcionalidad, p. 31. ${ }^{88}$ Para las vicisitudes de la subvención temporal de guerra, véase SÁnchez SANTiRó, "Guerra y restauración”. Para el contexto de la res- 
El gobierno, estructura y funcionamiento de la Real Hacien$\mathrm{da}$ ocuparon un lugar relevante en las reflexiones y propuestas de reforma que emprendieron diversos representantes de la economía política hispana, miembros por lo general de los reducidos círculos de ilustrados que servían al monarca en la propia administración hacendaria o en los diversos órganos de gobierno de la corona. ${ }^{89}$

Uno de los problemas más atendidos fue el que hizo hincapié en la necesidad de dar una constitución, de constitucionalizar el orden y régimen hacendario de la monarquía. Sin embargo, bajo este concepto cabían diversas propuestas de reforma. La más tradicional, en tanto se basaba en la antigua analogía corporativa de raíz antropomórfica, planteó la necesidad de dotar al real erario de una cabeza que se desempeñase como órgano rector que uniformase una estructura muy compleja tanto por los ramos fiscales de ingreso que administraba como por los cometidos que tenía que cubrir con dichos fondos, en el marco de un orden fiscal casuístico y particularista según la calidad de los contribuyentes, la situación de los espacios sobre los que tenía competencias y la posición que ocupaban las actividades económicas, en especial la minería de metales preciosos para el caso novohispano. Una nueva entidad rectora que debía estar acompañada de otra modalidad de funcionarios y de

tauración absolutista en Nueva España, Serrano Ortega, El sexenio absolutista.

${ }^{89}$ Para las prácticas culturales y políticas de los círculos ilustrados hispanos, véase Franco Rubio, "El ejercicio del poder". 
nuevas ordenanzas, como un instrumento básico para ejercer de forma adecuada el gobierno de la Real Hacienda. Todos estos elementos cristalizaron en los diversos ensayos emprendidos por el reformismo borbónico para implantar el régimen de intendencias de ejército y de provincia en el conjunto del imperio.

La otra acepción relevante del proceso de constitucionalización, no necesariamente alternativa o contraría en su contenido al anterior, ya que podía tener la capacidad de ser coadyuvante, consistió en asociar la salud financiera del erario regio a la salvaguarda de las propiedades y las rentas de los vasallos de la Monarquía; una protección que - se consideraba - sólo se podría lograr estableciendo un orden constitucional que determinase límites y reglas a las exigencias pecuniarias del monarca. No sólo había que actualizar y uniformar el régimen de gobierno de la Monarquía en materia de Hacienda con los antiguos instrumentos de un orden jurídico político de raíz jurisdiccional gracias a la introducción de nuevos tribunales, jueces administradores y ordenamientos (Juntas Superiores de Real Hacienda, superintendencias subdelegadas, ordenanzas de intendentes, etc.), sino que había que definir de forma nítida esferas de competencias, límites y restricciones al poder del soberano y salvaguardas a los haberes y rentas de los vasallos, además de liberalizar lo más posible las actividades económicas para lograr su bienestar. Se trata por tanto de una reforma mucho más radical dado el acento político que tenía. Unas propuestas que pudieron llevarse a término, aunque con una variación notable en su naturaleza política al proclamarse un nuevo titular de la soberanía, la nación española, con la crisis imperial de 1808-1810. 
Ambas vías fueron ensayadas y aplicadas con sus necesarias adaptaciones al real erario de Nueva España. La introducción del régimen de intendencias en 1786 y de la Constitución española de la Monarquía española de 1812 dotaron de una nueva fisonomía constitucional al régimen fiscal novohispano, en sus dos acepciones: al antropomórfico, que hacía del régimen de intendencias la culminación del proceso de reforma hacendaria, y el político, que hacía mutar el orden hacendario, al pasar de la esfera del rey al de la nación, y que institucionalmente se encarnó en la Hacienda pública.

En términos de afianzamiento de ambos procesos de constitucionalización en Nueva España, cabe señalar en el primero de los casos que el régimen de intendencias sufrió notables recortes y modificaciones que alteraron algunas facetas clave del proyecto, en especial la separación del cargo de la superintendencia general subdelegada de la figura del virrey, aunque en otras sí se ajustó a lo previsto; fue el caso de la Junta Superior de Real Hacienda de Nueva España, verdadero tribunal y órgano colegiado de gobierno que limitó la capacidad de actuación del alter ego del monarca en el virreinato. En el caso del orden constitucional gaditano, sus alcances en materia de Hacienda fueron mucho más limitados dado el estado de guerra civil que vivía Nueva España. Nunca se implantó el régimen de contribuciones (la contribución directa y los aranceles generales de aduanas) y de administración hacendaria (ayuntamientos y diputaciones como colectores y tesoreros de los caudales públicos, bajo el control de la Tesorería General de la Nación) previsto en la Constitución. 
Lo más relevante del nuevo orden constitucional fue que sirvió de valladar a las pretensiones de nuevos recursos fiscales y financieros promovidos al abrigo de una fiscalidad extraordinaria impulsada por las autoridades político militares del virreinato, que funcionaba en paralelo y al margen de los principios asentados en el orden constitucional. Un sistema en el que únicamente los representantes de la nación reunidos en Cortes podía aprobar tanto la reforma como la creación o derogación de las contribuciones que debían satisfacer los vecinos contribuyentes, verdaderos protagonistas del nuevo orden político. Que las contribuciones propuestas reuniesen algunos de los principios políticos que proclamaba la Constitución en materia de contribuciones (generalidad, igualdad, proporcionalidad), como sucedió con la contribución directa general y extraordinaria de diciembre de 1813 - creada a propuesta de la junta de arbitrios presidida por el virrey Félix María Calleja-, era una condición necesaria pero no suficiente. Sin su estudio y aprobación por los órganos políticos creados por el nuevo régimen político (Cortes generales, como núcleo básico, y como entes subsidiarios, las diputaciones provinciales y los ayuntamientos constitucionales) carecían de la legitimidad necesaria; sin su participación no podían aspirar a ser contribuciones liberales, y así lo denunciaron siempre los ayuntamientos constitucionales y las diputaciones provinciales, al igual que los propios contribuyentes, cuando se aprobaron y se exigió su cobro en Nueva España.

Si bien el régimen constitucional no logró desarrollar en Nueva España su función prefigurativa para implantar un régimen fiscal donde la contribución directa fuera la clave del orden tributario, ni la abolicionista, que la eliminación 
de las aduanas internas y las alcabalas, al ser una de las rentas fundamentales para los ingresos del virreinato (la guerra civil lo hacía del todo inviable), sí que mostró un potente desarrollo en su función restrictiva ante las pretensiones fiscales y financieras del virrey, los intendentes y los jefes militares, englobados ahora como representantes del Poder Ejecutivo. De hecho, las diputaciones provinciales y los ayuntamientos constitucionales hicieron inviable u obstaculizaron en grado sumo durante su corta existencia (1812-1814) el cobro de muchas de las contribuciones extraordinarias que se fueron creando tanto en las regiones como las que se plantearon para el conjunto del virreinato. La restauración absolutista de Fernando VII hizo no sólo posible la prolongación del régimen de contribuciones extraordinarias aprobadas entre 1810 y 1813 , sino que lo potenció a un nivel mucho mayor durante el periodo de 1814-1820, algo que vendría a denunciar y rectificar, sin bien de forma desigual según los contextos regionales, la restauración del régimen constitucional en 1820. En un contexto donde la pacificación de la mayoría del virreinato era un hecho constatable, los ayuntamientos constitucionales y las diputaciones provinciales novohispanas reconstituidos adoptaron un papel mucho más firme y beligerante en esta nueva coyuntura. 


\section{SIGLAS Y REFERENCIAS}

AGN Archivo General de la Nación, México.

Angulo Teja, María del Carmen

La Hacienda española en el siglo XVIII. Las rentas provinciales, Madrid, Centro de Estudios Políticos y Constitucionales, 2002.

Annino, Antonio (coord.)

La revolución novohispana, 1808-1821, México, Centro de Investigación y Docencia Económicas, Fondo de Cultura Económica, Consejo Nacional para la Cultura y las Artes, Instituto Nacional de Estudios Históricos de las Revoluciones de México, Fundación Cultural de la Ciudad de México, 2010.

Avella Alaminos, Isabel

"La experiencia de la partida doble en la Real Hacienda de Nueva España”, en Sánchez Santiró, Jáuregui e Ibarra, 2001, pp. 115-137.

Bertrand, Michel

Grandeza y miseria del oficio: los oficiales de la Real Hacienda de la Nueva España, siglos XVII y XVIII, traducción de Mario Zamudio, Zamora, Michoacán, México, El Colegio de Michoacán, Centro de Estudios Mexicanos y Centroamericanos, Fondo de Cultura Económica, Embajada de Francia, Instituto Mora, 2011.

Bовв, Bernard E.

The Vice-Regency of Antonio Maria Bucareli in New Spain, 1771-1779, Austin, University of Texas Press, 1962.

Brading, David A.

Mineros y comerciantes en el México borbónico, 1763-1810, México, Fondo de Cultura Económica, 1975. 
Bullock, Charles J.

"Direct and Indirect Taxes in Economic Literature", en Political Science Quarterly, 12 (1898), pp. 442-476.

Bustamante, Carlos María de

Cuadro histórico de la Revolución mexicana comenzada en 15 de septiembre de 1810 por el ciudadano Miguel Hidalgo y Costilla, cura del pueblo de Dolores, en el obispado de Michoacán, México, Imprenta de J. Mariano Lara, 1844, t. IV.

Camarero Bullón, Concepción

El debate de la Única Contribución. Catastrar las Castillas, 1749, Madrid, Tabapress, 1993.

Carrara, Angelo Alves y Ernest Sánchez Santiró (coords.)

Guerra y fiscalidad en la Iberoamérica colonial (siglos XVIIXIX), Brasil, México, Universidade Federal Juiz de Fora, Instituto Mora, 2012.

Chust, Manuel e Ivana Frasquet (eds.)

La trascendencia del liberalismo doceañista en España y en América, Valencia, Generalitat Valenciana, Conselleria de Cultura, Educació i Esport, 2004.

Chust, Manuel, y José Antonio Serrano

"El liberalismo doceañista en el punto de mira: entre máscaras y rostros", en Revista de Indias, LxviII: 242 (2008), pp. 39-66.

Clavero, Bartolomé

"Hispanus fiscus, persona ficta. Concepto del sujeto político en el ius commune moderno", en Quaderni Fiorentini per la storia del pensiero giuridico moderno, 11/12 (1982-1983), pp. 95-167.

"Cádiz, 1812: Antropología e historiografía del individuo como sujeto de Constitución”, en Quaderni Fiorentini per la storia del pensiero giuridico moderno, 42 (2013), pp. 201-279. 
Cовá NoH, Lorgio Gilberto

"La Hacienda pública en Yucatán: las vicisitudes del erario nacional y estatal, 1810-1839”, tesis de doctorado en historia, México, Instituto Mora, 2014.

\section{Colección de decretos}

Colección de decretos y órdenes que han expedido las Cortes generales y extraordinarias desde 24 de febrero de 1813 basta 14 de septiembre del mismo año, en que terminaron sus sesiones; comprende además el decreto expedido por las Cortes Extraordinarias en 20 del dicho mes. Tomo IV, Cádiz, Imprenta Nacional, 1813.

Comín, Francisco

Historia de la Hacienda pública, I. Europa, Barcelona, Crítica, 1996.

Dahmen, Wolfgang, Günter Holtus y Johannes Kramer u.a. (Hg.)

Lengua, historia e identidad, Perspectiva española e hispanoamericana/Sprache, Geschichte und Identität. Spanische und hispanoamerikanische Perspektiven, Romanistisches Kolloquium XVII, Tübingen, G.N. Narr, 2006.

Delgado Barrado, José Miguel

Aquiles y Teseos. Bosquejos del reformismo borbónico (17011759), Granada, Universidad de Granada, 2007.

Diego-Fernández, Rafael, y María del Pilar Gutiérrez

"José de la Cruz en el Theatro de la Nueva Galicia (18111821)”, en Serrano Ortega (coord.), 2014, pp. 229-274.

Donoso Anes, Alberto

"Nuevo método de cuenta y razón para la Real Hacienda en las Indias. La instrucción práctica y provisional en forma de advertencias comentada (27 de abril de 1784)", en Revista Española de Financiación y Contabilidad, xxvin: 101 (jul.-sep. 1999), pp. 817-862. 
Enciso Contreras, José

Cedulario de Zacatecas, 1554-1596, Zacatecas, Ayuntamiento de Zacatecas, Oñatiko Udala, Universidad Autónoma de Zacatecas, 1998.

Taxco en el siglo XVI. Sociedad y normatividad en un real de minas novohispano, Zacatecas, Ayuntamiento de Zacatecas, Universidad Autónoma de Zacatecas, 1999.

Zacatecas en el siglo XVI. Derecho y sociedad colonial, Zacatecas, Ayuntamiento de Zacatecas, Universidad de Alicante, Instituto Zacatecano de Cultura Ramón López Velarde, 2000.

Fonseca, Fabián de y Carlos de Urrutia

Historia de Real Hacienda, México, Imprenta de Vicente G. Torres, 1845-1853, 6 tomos.

Fontana, Josep y Ramón Garrabou

Guerra y Hacienda. La Hacienda del gobierno central en los años de la guerra de la independencia (1808-1814), Alicante, Instituto de Estudios Juan Gil-Albert, 1986.

Franco Rubio, Gloria A.

"El ejercicio del poder en la España del siglo xviri. Entre las prácticas culturales y las prácticas políticas", en Melánges de la Casa de Velázquez, t. 35-1 (2005), pp. 51-77.

Garriga, Carlos

"Orden jurídico e independencia política. Nueva España, 1808-México, 1821”, en Annino (coord.), 2010, pp. 35-124.

Garriga, Carlos (coord.)

Historia y Constitución. Trayectos del constitucionalismo hispano, México, Centro de Investigación y Docencia Económicas, Instituto Mora, El Colegio de Michoacán, ELD: HICOES, El Colegio de México, 2010.

Gerhard, Peter

Sintesis e indice de los mandamientos virreinales, 1548-1553, México, Universidad Nacional Autónoma de México, 1992. 
González, María del Refugio

Ordenanzas de Minería de la Nueva España formadas y propuestas por su Real Tribunal, México, Universidad Nacional Autónoma de México, 1996.

Hausberger, Bernd

La Nueva España y sus metales preciosos. La industria minera colonial a través de los libros de cargo y data de la Real Hacienda, 1761-1767, Madrid, Iberoamericana, 1997.

Howe, Walter

The Mining Guild of New Spain and its Tribunal General, 1770-1821, Nueva York, Greenwood Press, 1949.

Informe

Informe de la Comisión extraordinaria de Hacienda, sobre un nuevo sistema de contribución directa y extinción de rentas provinciales y estancadas, presentado a las Cortes generales y extraordinarias en 6 de julio de 1813, Cádiz, Imprenta de D. Diego García Campoy, 1813.

JÁuregui, Luis

La Real Hacienda de Nueva España. Su administración en la época de los intendentes (1786-1821), México, Universidad Nacional Autónoma de México, 1999.

Lalinde Abadía, Jesús

“La 'persona ficta' en el escenario europeo", en Anuario de Historia del Derecho, 60 (1990), pp. 5-28.

Lasarte Álvarez, Javier

Las Cortes de Cádiz. Soberanía, separación de poderes, Hacienda, 1810-1811, Madrid, Marcial Pons Historia, Universidad Pablo de Olavide, 2009.

La contribución extraordinaria de guerra de la Junta Central y las Cortes de Cádiz, 1810-1813. Orígenes de la imposi- 
ción personal en España, Cádiz, Servicio de Publicaciones de la Universidad de Cádiz, 2012.

Lassaga, Juan Lucas de y Joaquín Velásquez de León Representación que a nombre de la Minería de esta Nueva España, hacen al Rey Nuestro Señor los apoderados de ella..., México, D. Felipe Zúñiga y Ontiveros, 1774.

López Castellanos, Fernando

Liberalismo económico y reforma fiscal. La contribución directa de 1813, Granada, Universidad de Granada, Fundación Caja de Granada, 1995.

"De las arcas reales a las arcas de la nación. El presupuesto y la contabilidad pública como valladares frente a la arbitrariedad gubernamental”, en Comptabilités, 3 (2012), pp. 1-18 [URL: http://comptabilites.revues.org/760, consulado el 17 de octubre de 2014].

López de Goicoechea Zabala, Javier

"La Imago Regis en Las Partidas alfonsinas", en Saberes. Revista de estudios jurídicos, económicos y sociales, 1 (2003), separata.

Lorente Sariñena, Marta

"Esencia y valor del constitucionalismo gaditano (Nueva España: 1808-1821)”, en ANNino (coord.), 2010, pp. 293-383.

LuDLOw, Leonor (coord.)

El sustento económico de las revoluciones en México, México, Universidad Nacional Autónoma de México, 2013.

Marichal, Carlos

Bankruptcy of Empire. Mexican Silver and the Wars between Spain, Britain and France, 1760-1810, Cambridge, Cambridge University Press, 2007. 
Martínez de Montaos, Román et al.

El pensamiento hacendístico liberal en las Cortes de Cádiz, edición y estudio preliminar de Fernando López Castellanos, Madrid, Instituto de Estudios Fiscales, Ministerio de Economía y Hacienda, 1999.

Moreno, Roberto

Joaquín Velázquez de León y sus trabajos científicos sobre el Valle de México: 1773-1775, México, Universidad Nacional Autónoma de México, 1977.

North, Douglass

Institutions, Institutional Change, and Economic Performance, Cambridge, Cambridge University Press, 1990.

Pietschmann, Horst

Las reformas borbónicas y el sistema de intendencias en Nueva España. Un estudio administrativo, México, Fondo de Cultura Económica, 1996.

"Nación e individuo en los debates políticos de la época preindependiente en el Imperio Español (1767-1812)", en DAHMEN, Holtus, Kramer, 2006, pp. 22-50.

Portillo Valdés, José María

Crisis atlántica. Autonomía e independencia en la crisis de la monarquía hispánica, Madrid, Fundación Carolina, Marcial Pons, 2006.

"Entre la historia y la economía política: orígenes de la cultura del constitucionalismo", en GARRIGA (coord.), 2010, pp. 27-57.

Pro Ruiz, Juan

Estado, geometría y propiedad. Los orígenes del catastro en España, 1715-1941, Madrid, Subdirección General de Estudios y Estadística, Ministerio de Economía y Hacienda, 1992.

Real Ordenanza

Real Ordenanza para el establecimiento e instrucción de In- 
tendentes de ejército y provincia en el Reino de la Nueva España, Madrid, 1786, De orden de Su Majestad.

Recopilación

Recopilación de las Leyes de los Reynos de Indias, mandadas imprimir y publicar por la Majestad Católica del Rey Don Carlos II nuestro Señor, 4 tomos, Madrid, Julián de Paredes, 1681 [consulta: http://www.congreso.gob.pe/ntley/LeyIndiaP.htm].

Rodríguez Campomanes, Pedro

Tratado de la regalía de amortización, Madrid, Imprenta Real de la Gaceta, 1765.

Rodríguez de San Miguel, Juan N.

Pandectas Hispano-megicanas, México, Librería de J.F. Sosa, 1852 , t. III.

Rodríguez García, Vicente

El fiscal de Real Hacienda en Nueva España (Don Ramón de Posada y Soto, 1781-1793), Oviedo, Universidad de Oviedo, 1985.

Rojas, Beatriz

"Las ciudades hispanas ante la crisis: entre la antigua y la nueva Constitución", en Historia Mexicana, Lvin:1(229) (jul.-sep. 2008), pp. 287-324.

Rojas, Beatriz (coord.)

Cuerpo político y pluralidad de derechos. Los privilegios de las corporaciones novohispanas, México, Instituto Mora, Centro de Investigación y Docencia Económicas, 2007.

Sánchez Santiró, Ernest

"Privilegio versus monopolio. El cuerpo de minería de Nueva España durante la segunda mitad del siglo xviII”, en RoJAs (coord.), 2007, pp. 215-246. 
Las alcabalas mexicanas (1821-1857). Los dilemas en la construcción de la Hacienda nacional, México, Instituto Mora, 2009.

"Guerra y restauración del antiguo régimen fiscal en Nueva España: la Junta Menor de Arbitrios de 1815”, en Jabrbuch für Geschichte Lateinamerikas (JbLA), 48 (2011), pp. 57-81.

"La irrupción del liberalismo fiscal en Nueva España: la contribución directa general y extraordinaria (1813-1815)", en América Latina en la Historia Económica, 37 (ene.-abr. 2012), pp. 7-35.

Corte de caja. La Real Hacienda de Nueva España y el primer reformismo fiscal de los Borbones (1720-1755). Alcances y contradicciones, México, Instituto Mora, 2013.

Sánchez Santiró, Ernest, Luis Jáuregui y Antonio Ibarra

Finanzas y política en el mundo iberoamericano. Del antiguo régimen a las naciones independientes, México, Universidad Autónoma del Estado de Morelos, Instituto Mora, Universidad Nacional Autónoma de México, 2001.

Serrano Ortega, José Antonio

"Liberalismo y contribuciones directas en México, 18101835”, en Chust y Frasquet (eds.), 2004, pp. 187-210.

Igualdad, uniformidad, proporcionalidad. Contribuciones directas y reformas fiscales en México, 1810-1846, México, Instituto Mora, El Colegio de Michoacán, 2007.

Serrano Ortega, José Antonio (coord.)

El sexenio absolutista, los últimos años insurgentes. Nueva España (1814-1820), México, El Colegio de Michoacán, 2014.

Solórzano y Pereira, Juan de

Política indiana. Sacada en lengua castellana de los dos tomos del Derecho y gobierno municipal de las Indias Occidentales que más copiosamente escribió en la latina..., Madrid, por Diego Díaz de la Carrera, 1648. 
Tena Ramírez, Felipe

Leyes fundamentales de México, 1808-1975, México, Porrúa, 1975.

TePaske, John J. y Herbert S. Klein

Ingresos y egresos de la Real Hacienda de Nueva España, México, Instituto Nacional de Antropología e Historia, 1986, t. 1.

Torres SÁnchez, Rafael (ed.)

War, State and Development. Fiscal-Military States in Eighteenth Century, Pamplona, Eunsa, 2007.

Valladares, Rafael

Banqueros y vasallos. Felipe IV y el medio general (16301670), Cuenca, Ediciones de la Universidad de Castilla-La Mancha, 2002.

Valle Pavón, Guillermina del

"Financiamiento de los mercaderes de México para la lucha contra la invasión napoleónica en España y la contrainsurgencia”, en LudLOw (coord.), 2013, pp. 67-93.

Ventura Beleña, Eusebio

Recopilación sumaria de todos los autos acordados de la Real Audiencia y Sala del Crimen de esta Nueva España, México, Universidad Nacional Autónoma de México, 1981, 2 tomos. 
